\title{
THE ASSOCIATION BETWEEN THE SUCCESS OF INFORMATION SYSTEMS AND CRISES MANAGEMENT (A THEORETICAL VIEW AND PROPOSED FRAMEWORK)
}

\author{
iD Mahmoud Hany \\ M. Dalloul ${ }^{1}$ \\ (iD) Zuraeda binti \\ Ibrahim $^{2+}$ \\ (iD) Sharina Tajul \\ Urus $^{3}$
}

\author{
${ }^{1,2,3}$ Faculty of Accountancy, University Technology MARA, Malaysia \\ 'Email:mahmoooud21@gmail.com \\ ¿Email:zurea229@uitm.edu.my \\ ${ }^{s}$ Email: sharena675@uitm.edu.my
}

check for
updates

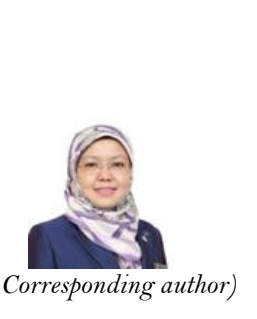

(+ Corresponding author)

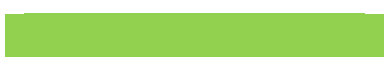

\section{Article History \\ Received: 15 November 2021 Revised: 27 December 2021 Accepted: 10 January 2022 Published: 21 January 2022}

\section{Keywords}

Crisis management Information system Systems quality Information quality Service quality Use, and user satisfaction Pre-crisis management Post-crisis management.

\begin{abstract}
Crises and disasters often motivate the adoption of efficient and effective information systems (IS) that are capable of supporting the organizations in the face of future crises. Though previous studies have recognized the role of IS in crisis management, there is a lack of a comprehensive IS model that can measure the effectiveness of crisis management. The absence of an integrated empirical model that could regulate the association between the success of the information system and crisis management also warrants further consideration. This paper aims to offer a comprehensive and integrated framework for the relationship between information systems and crisis management. The theoretical lens of this paper is based upon DeLone and McLean's IS Success Model which includes four interrelated dimensions: systems quality; information quality; service quality; use and user satisfaction. The effectiveness of crisis management at different stages, namely pre-crisis management, crisis management, and post-crisis management, was adopted from Mitroff's model. A qualitative methodology was employed, incorporating a comprehensive search and review of articles obtained from scientific search engines, including Google Scientific, EBSCO, and Emerald. The outcome from this concept paper sheds light onto IS and crisis management research areas by formulating a comprehensive IS measurement model for crisis management. The formulated framework is beneficial for the future empirical work in the area of crisis management. It also presents a proposal for possible experimental paths between the variables of that framework to facilitate enhanced understanding via accurate measurement.
\end{abstract}

Contribution/ Originality: This article highlights a comprehensive and integrated framework on the relationship between information systems and crisis management. It organizes the relationships into a model that can be measured empirically with sets of appropriate attributes. It also presents a proposal for possible experimental paths between the variables of the framework.

\section{INTRODUCTION}

The world is witnessing a new century of technology and information. Big data and information do not achieve the desired value unless they are able to play a role in supporting the decision maker and ensure that information is available with the appropriate accuracy and speed. Thus, achieving a full understanding of information and the nature of the relationships between different items of information requires the adoption of modern and effective techniques 
and devices that contribute to the methods of entering, storing, processing and recalling information with high efficiency (Barbakh, 2013; Ekman, Dahlin, \& Keller, 2021; Shamim, Zeng, Shariq, \& Khan, 2019; Spanò \& Ferri, 2019). Moreover, modern life is characterized by a high level of technological and scientific progress, which would affect many sectors in various fields of work. Business organizations today are required to keep pace with this progress, as they need information systems with high capabilities that can keep up with the fast-moving and complex work environment. It is essential for decision-making that valuable and accessible information is available when needed. Information is essential to ensure any progress at various levels, whether social, institutional, or governmental; there can be no knowledge or rational decision-making without information. Modern technology has made possible a kind of transparency in dealing and benefiting from information in various possible ways. Information systems are one of the main resources for any organization, enabling organizations to achieve and build the decision-making process on a real basis that enhances the rationalization of economic resources and achieves organizational goals (Abualoush, Obeidat, Tarhini, \& Al-Badi, 2018; Cahyono \& Suryani, 2020; Dwivedi et al., 2021; Ghoneim, 2004; Gudipudi \& Srivastav, 2016; Pohan, 2021; Ravichandran, 2018). The organization's exposure to crises and disasters of all kinds is one of the main motivations for adopting efficient and effective information systems capable of supporting these organizations in the face of crises. Achieving effectiveness in the organization's dealing with crises depends mainly on the availability of the components and elements necessary to manage a crisis before it occurs, during its occurrence, and after its end. Information is one of the basic constituents that reduce uncertainty and increase the level of confidence of the decision-maker during crises. Providing valuable and appropriate information to the decision maker at all administrative levels depends on the availability of effective information systems, which would enable the organization to manage and deal with the crisis, starting with forecasting, warning, planning and coordinating, as well as choosing procedures and providing scenarios, in addition to dealing with the potential effects of the crisis. Moreover, it must facilitate work to restore the normal situation while drawing lessons that will assist in facing similar crises in the future (Aloun \& Attieh, 2018; Bakir, 2016; Chabani \& Chabani, 2014; Chahed \& Zergoune, 2017; Zwyalif, 2015). Based on the foregoing, this paper proposes a framework for measuring the association between information system success and crisis management, consistent with the model of DeLone and McLean (1992). The significance of this article stems from the fact that very few models associating information systems and crisis management are available and those that do exist are incomplete and have not been sufficiently validated, empirically. This article is structured as follows: First, the background and literature for this article are presented, including the dimensions of information systems and their success, crisis management and its dimensions, followed by a review of the association between information systems and crisis management as outlined in the literature. Then a model or framework is proposed that derives from conceptions of this relationship. This is followed by suggestions for ensuring the success of both information systems and crisis management, as well as a proposal for experimental paths between variables to facilitate the process of measuring relationships. Following the conclusion, recommendations are made for further research.

\section{BACKGROUND AND LITERATURE}

The core objective of this article is to develop an integrated framework that considers the relationship between the information systems and crisis management. Toward achieving that goal, this section will address the literature related to the success of information systems and the literature on crisis management and literature clarifying the relationship between them. Shannon and Weaver (1949) introduced information theory or a mathematical theory of communication, through which the information produced by the communication system is measured on several levels; namely, the technical level, the level of semantics, and the level of effectiveness. Mason (1978) introduced the theory of the influence of information, which further divided the levels of measurement of information produced by information systems into the level of production, the level of the product, the information receiver, the effect on the receiver, and the effect on the system. DeLone and McLean (1992) presented a model showing the levels that can be 
applied to information systems to measure their success as follows: system quality, information quality, use, user satisfaction, individual influence, and organizational influence. In 2002, DeLone and McLean (2002) conducted a review of the literature to revise and reformulate their previous model. In 2003, they developed a new model that was clearer and more accurate in measuring the success of information systems (DeLone \& McLean, 2003). In the revised model, they identified the following levels: system quality, information quality, quality of services, usage, user satisfaction, and net benefits. Thus, there are three main levels or aspects by means of which the success of any information system can be determined. They are: i) The quality level of the information systems: this is a level related to the information system itself, including the technology it depends on in its creation or the outputs and services it provides. ii) The level of influence on the user: This is a level related to the users of the information system who handle and estimate the quality of the information system. This is indicated through the volume of their use of the system and the extent of their satisfaction with the system. iii) The general or final impact level: This refers to a level related to the final benefits of the information system and the extent to which it achieves the objectives for which it was set up, whether at the level of the organization, the individual, or the beneficiaries of this system, according to their diversity and differences.

System Quality: A collection of constructs linked to the information system determines the quality of the system, and include the required features of the information system itself, which provides the information. These constructs and characteristics are: system reliability (DeLone \& McLean, 2016; Jaafreh, 2017) ease of use (DeLone \& McLean, 2016; Sorongan \& Hidayati, 2020) response time (DeLone \& McLean, 2016; Putra \& Setiawan, 2020) system flexibility and maintainability (Aldegis, 2018; DeLone \& McLean, 2016) ease of learning (DeLone \& McLean, 2016; Putra \& Setiawan, 2020) integration with other systems (Aldegis, 2018; Ali \& Younes, 2013) sophistication (DeLone \& McLean, 2016; Gorla , Somers, \& Wong, 2010) ease of access, accessibility, availability (DeLone \& McLean, 2016; Susilawati \& Jerry, 2018) security (DeLone \& McLean, 2016; Putra \& Setiawan, 2020) understandability (Aldholay, Isaac, Abdullah, \& Ramayah, 2018) adaptability (Jaafreh, 2017; Nurhayati, Iss, \& Sk, 2017) system features, system accuracy (Jaafreh, 2017; Sedera \& Gable, 2004) efficiency (Shagari, 2018) alignment, differentiation (Aldegis, 2018) currency, user friendliness (Jaafreh, 2017) personalizability, system interactivity, formality (DeLone \& McLean, 2016) user pre-emptiveness (Romi, 2013) correctness (Ali \& Younes, 2013) user requirements, and customization (Sedera \& Gable, 2004), as well as other system metrics such as functionality, relevance, timeliness, system productivity, usability, portability, convenience, and intuitiveness. Furthermore, system quality is linked with the presence or absence of defects in the system, the consistency and flexibility of the user's interface, documentation quality, and program code maintainability.

Information Quality refers to the desirable characteristics of the system outputs. Information quality is the level to which information displays the needed advantages and is also linked to the quality of the system inputs and outputs. The higher the quality of the information, the higher its contribution to reducing uncertainty and hence improving the quality of the decision. Therefore, information quality is the yield of the system that satisfies user wants and requirements. These characteristics for information are accuracy (DeLone \& McLean, 2016; Sorongan \& Hidayati, 2020) availability, accessibility (Putra \& Setiawan, 2020) relevance, suitability (DeLone \& McLean, 2016; Putra \& Setiawan, 2020) completeness (DeLone \& McLean, 2016; Putra \& Setiawan, 2020) timeliness (DeLone \& McLean, 2016; Sorongan \& Hidayati, 2020) understandability (DeLone \& McLean, 2016; Jaafreh, 2017; Rahi \& AbdGhani, 2019) reliability (DeLone \& McLean, 2016; Jaafreh, 2017) the format of input/output (Jaafreh, 2017; Susanto, 2017) usability, usefulness (DeLone \& McLean, 2016; Tam \& Oliveira, 2016) conciseness, concise representation (Jaafreh, 2017; Romi, 2013; Sedera \& Gable, 2004) precision (Jaafreh, 2017) currency (DeLone \& McLean, 2016) appropriateness, interpretability (Romi, 2013) assurance (Shagari, 2018) content (Gorla et al., 2010; Susanto, 2017; Wu \& Wang, 2006) context and linkage quality (Wu \& Wang, 2006) transaction processing (Mkonya, Jintian, \& Kyando, 2017) neutrality (Kanakriyah, 2016) punctuality (Putra \& Setiawan, 2020) up-to-date (Sorongan \& Hidayati, 
2020; Tam \& Oliveira, 2016) comprehensive, and organised (Aldholay et al., 2018). Other information metrics include convenience, sincerity, believability, ease of manipulation, error free, security, objectivity, and reputation.

Service Quality concerns the value of the assistance that system users obtain from the Information system department and IT support staff across all of its services or for specific Information systems. It is also interpreted as estimating the extent of the service given to the client, whether it is in line with the client's expectations, and whether the performance of service matches the expectations set by the client. In other words, service quality is a set of attributes related to the services offered by Information systems to clients. Those characteristics for service are: service reliability (DeLone \& McLean, 2016; Jaafreh, 2017; Rahi \& AbdGhani, 2019) assurance (AL-Ja'afreh, 2011; Rahi \& AbdGhani, 2019) responsiveness (AL-Ja'afreh, 2011; DeLone \& McLean, 2016; Putra \& Setiawan, 2020) empathy of the IT personnel staff (DeLone \& McLean, 2016; Putra \& Setiawan, 2020) security (Romi, 2013) tangibles (AL-Ja'afreh, 2011; Jaafreh, 2017) follow-up service (Putra \& Setiawan, 2020) functionality, interactivity (Aldholay et al., 2018). Other service metrics such as accuracy, technical competence, and timeliness are also included.

System Use; the level and manner in which users and clients utilize the abilities of an information system. In other words, it refers to the use consumption of an information system or its yield expressed in terms of real or self-reported usage, or the extent to which end-users use the outcomes provided by the information system. The use is action by the user to operate and learn from the information system. The measures of usage include: frequency of use (Aldholay et al., 2018; DeLone \& McLean, 2016) amount of use (Jaafreh, 2017) use nature, use extent, use appropriateness (DeLone \& McLean, 2016) the degree of system use, responsiveness, adaptability, effectiveness (Romi, 2013) use duration (Aldholay et al., 2018; DeLone \& McLean, 2016) reports requested (AL-Ja'afreh, 2011; Jaafreh, 2017) intention to reuse, attitude toward use, thoroughness of use (DeLone \& McLean, 2016) usage level, motivation of use, knowledge (Putra \& Setiawan, 2020) security (Shagari, 2018). Purpose of use is another use metric.

User satisfaction; This is the degree to which the user of the information systems senses that the system fulfils his or her information wants including users' degree of satisfaction with the information system itself, the reports it produces, and support services. It refers to the beneficiary's response to the use of information system's output, approval or likeability of the information system and the output. It is associated with attitudes towards information systems. The measure of user satisfaction is overall satisfaction with information systems applications; that is, user information satisfaction and overall satisfaction as a single measurement (AL-Ja'afreh, 2011; DeLone \& McLean, 2016; Jaafreh, 2017). Single items to measure user satisfaction include semantic differential scale to evaluate behaviors and satisfaction with the systems, and multi-attribute scale to measure user information satisfaction. Other satisfaction metrics include achievement of task, availability of system, productivity, robustness, efficiency (Romi, 2013), user feeling, and use satisfaction (Putra \& Setiawan, 2020).

Net Impacts: the net impact is defined as the level to which information systems contribute or do not contribute to the success of organizations, individuals, societies, groups, industries, countries, etc. They represent the end point in measuring the success of the information system. The net effect measures the results of the system, which requires comparing it with the goal of the system. Therefore, the construction of this measurement depends largely on the context and is the most diverse compared to other dimensions of the success model. Examples of net impact benefits are improved decision-making, improved productivity, time savings, reduced research costs, increased transactions, cost savings, improved returns, efficiency and market expansion, consumer welfare, job creation, economic development. Measures that capture the final results of using and implementing the system are considered one of the most essential success measures for users and beneficiaries of the systems. There is an abundance of measurement methods for this variable, whether at the level of individual, organizational, industrial, collective or societal analysis (DeLone \& McLean, 2016; Putra \& Setiawan, 2020). The individual and organizational effect are the most common influences. At the individual level, the dimensions or elements for measuring the individual impact of information systems include: innovation of task, or the level to which the system assists users to create and experiment with new thoughts in their job; task productivity, or the degree to which the system improves user output per unit time; 
administrative control, or the level to which the system assists in regulating job processes and performance; and customer fulfilment, or the degree to which the system helps the user create value for the company's external or internal clients (DeLone \& McLean, 2003, 2016; Sorongan \& Hidayati, 2020). At the organizational level, profitability measures are preferable and appropriate in the context of profit-oriented private enterprises, but less suitable for governmental and non-profit organizations, where achieving public and social value is its objective. In addition, measures of impact at the organizational level may be qualitative. For example, the dimensions or elements of evaluating the organizational impact of information systems can be represented in three classifications of organizational influences: informational, interactive, or transactional, and strategic. Informational influences include access to information, quality of information, and sub-elements of information flexibility. Benefits of transactional influences include efficiency of communication, system development efficiency, and sub-components of business efficiency. Strategic benefits or influences consist of alignment, competitive benefit, and customer relationship benefits. The above are tools that measure the effects of information systems and are considered an important and necessary contribution to measuring the success of those information systems.

DeLone and McLean (2016) indicated the need to develop such tools, expand their scope, and verify their validity. Different measures of impact are also suitable for different kinds of systems with different influence targets. Over time, crisis management scholars have produced several models to illustrate fundamental progress in a crisis. For example, Mitroff, Shrivastava, and Udwadia (1987); Mitroff (1994); Pearson and Mitroff (1993) described a fivestage model consisting of sign detection, preparedness/preventing, containment/harm control, retrieval, and learning. Those five stages are categorized into three strategies of crisis management: proactive, interactive, and reactive. The stages represent the steps achieved before, during, and after the crises. Proactive Crisis Management: consists of actions that, if completed correctly and effectively, can prevent several crises from happening. It has two specific phases; namely, the signal detection phase and the preparation/prevention phase (A'dwan, 2019; Al Eid \& Arnout, 2020; Ershadi \& Shemirani, 202 1; Hanna, Abdul Aziz, \& Najib, 2018; Leta \& Chan, 2021; Sofyan et al., 2021 ; West, 2020). The signal detection phase is the first phase where crisis-warning cues are recognized. This phase comprises monitoring and heeding early warning signals that indicate the possibility of a crisis developing. It concerns the realization of initial signs of crises and the description of crisis signals. The crisis-prone institution is likely to ignore the signs of crises, while the crisis-prepared institution can recognize even very weak signals (Abdalbaqi, 2021; Alpaslan \& Mitroff, 2021; Berbekova, Uysal, \& Assaf, 2021; Dayour, Adongo , Amuquandoh, \& Adam, 2020; Ferwanah, 2019; Kao, Wang, \& Farquhar, 2020; Le \& Phi, 202 1; Ricke, 2020; Tokakis, Polychroniou, \& Boustras, 2019; Wut, Xu, \& Wong, 2021). The preparation/prevention phase includes exploring and analyzing crisis risk factors and reducing the possible infliction. The prevention stage also involves effective investigation for defects and possible obstacles. It is strictly associated with the first step because both preparedness and prevention are necessary not just when the signs have been recognized, but also when the crises are still under control (Abdalbaqi, 2021; Aldao, Blasco, Espallargas, \& Rubio, 2021; Alpaslan \& Mitroff, 2021; Alteneiji, Ahmed, \& Saboor, 2020; Berbekova et al., 2021; Dayour et al., 2020; Kao et al., 2020; Le \& Phi, 2021 ; Nizamidou \& Vouzas, 2020; Ricke, 2020; Sofyan et al., 2021; Sumukadas, 2021; Tokakis et al., 2019; West, 2020; Wut et al., 2021). Consequently, the first and second stages are both classified as proactive strategies of crisis management. Reactive crisis management, on the other hand, consists of actions performed after a crisis has occurred to contain its harm and recover from its consequences. This stage also has two (2) essential phases: the containment/harm limitation stage. and the recovery stage. The containment/damage limitation phase relates to a crisis outbreak and expansion. Crisis harm prevention aims to limit the damage from engulfing and spilling over into other unaffected divisions of the institution. It includes efforts to control the harm, not only material damage but also the distribution of information, because once the information is spread through the media, the harm could be amplified (A'dwan, 2019; Abdalbaqi, 2021; Al Eid \& Arnout, 2020; Alpaslan \& Mitroff, 2021; Berbekova et al., 2021; Dayour et al., 2020; Ershadi \& Shemirani, 2021; Hanna et al., 2018; Kao et al., 2020; Leta \& Chan, 2021; Ricke, 2020; Thielsch, Roseler, Kirsch, Lamers, \& Hertel, 
2020; Tokakis et al., 2019; Wut et al., 2021). The recovery phase, on the other hand, refers to restoring the status to normal business operations. This activity includes improving and performing examined recovery mechanisms. The institutional objective is to return to regular performances by recovering the damages of physical and immaterial assets and rebuilding relationships within the institution and with the outside public (Al Eid \& Arnout, 2020; Aldao et al., 2021; Alpaslan \& Mitroff, 2021; Alteneiji et al., 2020; Berbekova et al., 2021; Dayour et al., 2020; Ershadi \& Shemirani, 2021; Ferwanah, 2019; Le \& Phi, 2021 ; Ricke, 2020; Sofyan et al., 2021; Sumukadas, 2021 ; Thielsch et al., 2020; Tokakis et al., 2019; West, 2020; Wut et al., 2021). Interactive crisis management involves the educational element, which is an examination of the other actions. The learning stage includes evaluating the crisis management efforts and adding to the institution's memory. Crisis management involves interpreting and criticising to learn from it by constantly learning and reassessing to improve on what has been done previously. It further includes the evaluation of all previous steps with a view to reviewing and critiquing them to see what was done well and what was done poorly in order to better manage crises in the future (Abdalbaqi, 2021; Al Eid \& Arnout, 2020; Alpaslan \& Mitroff, 202 1; Berbekova et al., 202 1; Dayour et al., 2020; Ershadi \& Shemirani, 2021; Ferwanah, 2019; Leta \& Chan, 2021 ; Nizamidou \& Vouzas, 2020; Ricke, 2020; Tokakis et al., 2019; Wut et al., 2021).

As studies by A'dwan (2019); Hanna et al. (2018); Aloun and Attieh (2018); Chahed and Zergoune (2017); Abdul Razzaq (2011) and Ghanem (2011) have shown, an information system has prominent and important roles at the different stages of crises. During the pre-crisis stage, the role of an information system is to define the general policy and objectives of the organization. It should contribute to the preparation of assessments of potential risks and threats to the crisis. Additionally, it should assist the management to identify crises or predict their possibility. An organization should build appropriate information bases for each type of crisis potentially facing the organization so that it could easily identify the indicators and evidence that would predict the occurrence of the crisis. Information during this stage could also contribute to preparing a crisis work team with experience and training in the field of crises. Information that should be made available before the crisis includes, but is not restricted to, information about the phenomena that warn of the imminent occurrence of the crisis, previous experiences related to the crisis (whether at the local level or at the international level), as well as various data related to hospitals, health centers, fire stations, and police departments (in the case of crises that result in human and material losses). It is also important that data related to experts who have experience in managing and dealing with crises are included in the database. During the crisis, some of the important roles of information systems are to maintain the information flow with the crisis management centers. Information systems assist by providing access to experts and advisors according to the appropriate disciplines of the crisis; they help to modify pre-prepared plans to face the crisis and its developments as it unfolds, and to identify and provide appropriate alternatives for countering the crisis. Availability of a sufficient amount of clear and precise information and continuously updated data about the crisis and its development are vital. In this stage, a communication officer responsible for linking experts with the sites of the occurrence of the crisis is needed. With regard to the post-crisis stage, information systems must enable the organization to update the basic information base of the various crisis management centers. They should assist in analyzing the crisis and the causes of its occurrence and come up with results that can be used later. The IS is expected to also identify deviations related to facing the crisis and the possibility of correcting them before facing similar future crises. Thorough documentation is needed for learning to take place and ensure appropriate steps are taken if the pre-crisis situation arises again in the future. The document should contain a detailed and accurate summary of the crisis at the time of its occurrence, the circumstances surrounding it, and all the procedures that were followed in the context of crisis management. In addition, the documentation also must contain an evaluation of the crisis management methodology, in terms of the size of material and human losses. The goal is to provide information to decision-makers managing the situation of crisis operations that will enable them to reduce the losses resulting from the crisis while appreciating the speed needed to face the situation. At this stage, IS should provide the means to mitigate the negative effects of the crises, 
anticipate their occurrence, and determine whether they are likely to occur again in the future. In other words, IS should assist management in identifying preventive, corrective, and remedial measures.

\section{PROPOSED FRAMEWORK}

Based on the literature review, we have constructed a proposed conception and model that highlights the association between the success of information systems and crisis management. Figure 1 illustrates the proposed framework for this article. The framework consists of two parts; the first part is represented by the success variables of information system (system quality, information quality, service quality, system use, and user satisfaction). The second part, relating to the impact of the system, is represented by crisis management, which is subdivided into three stages and their associated tasks: pre-crisis management, management during the crisis, and post-crisis management. where each classification includes the tasks related to it. The framework explains how the dimensions of the success of an information system independently and through their interactions affect the crisis management effectiveness in the organization (the level of impacts). Thus, it can be said that the success of an information system is related to and affects the crisis management of the organization. Successful management of any crisis that the organization may face is one of the main objectives for adopting and developing an information system.

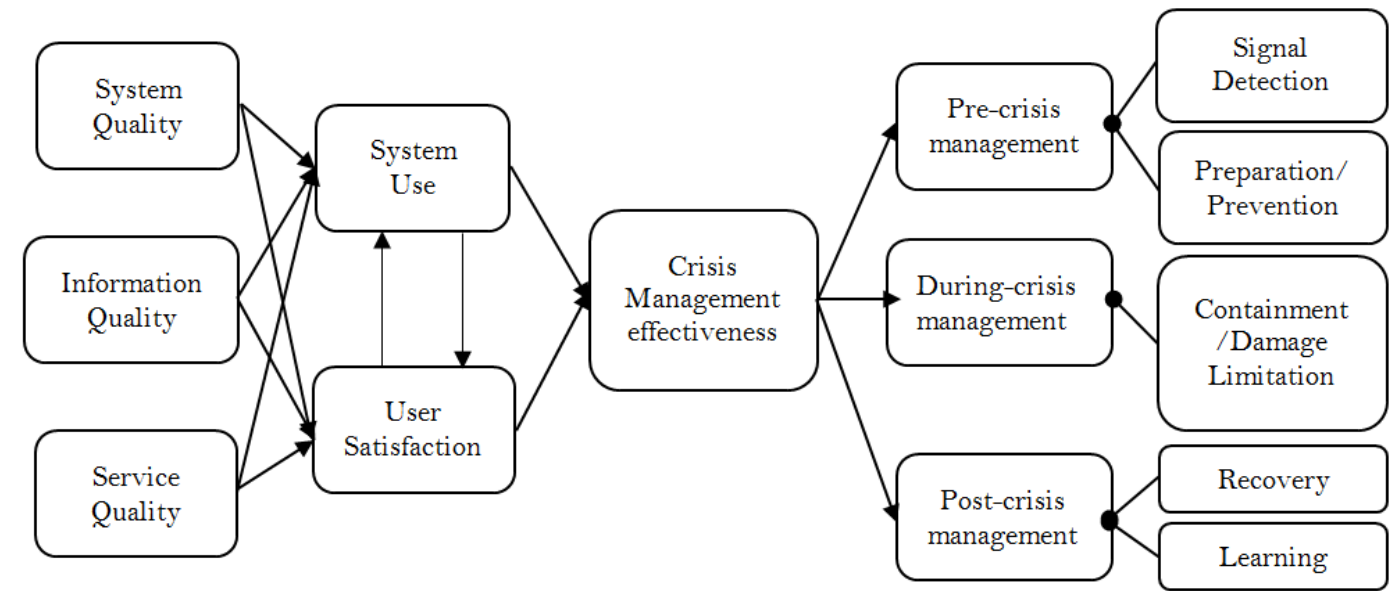

Figure 1. Proposed framework (ISs-CM Model).

From the literature discussed earlier, it is clear that the quality of an information system influences the performance of individuals and the performance of the organization as a whole. The presence of high-quality information systems creates a situation of high usage among users, which increases their satisfaction and enhances their intention to reuse the system because it meets their information needs and facilitates their work. All these benefits ultimately lead to the realization of the objectives for which the system is developed and the achievement of organizational objectives.

The successful management of crises and overcoming their impact is among those reasons that urge the organization to adopt an advanced and high-quality information system. This paper argues that improving the effectiveness of crisis management is among the benefits that are expected to be achieved through the adoption and implementation of a successful information system. Thus, in the framework proposed here, the level of impact (or the overall or ultimate benefits that accrue) is considered "crisis management effectiveness".

The current article is the first to suggest studying this variable - crisis management effectiveness - within the model of the success of information systems. This would expand the applications of DeLone and McLean (2002) IS success model and open the way for empirical studies to suggest other dependent variables, increasing awareness of the importance of adopting effective information systems in organizations, and understanding their impact on the various business and sectors of the organization. Expanding the scope of empirical studies towards conducting more studies on the association between the success of an information system and crisis management would achieve a better 
understanding and perception of this relationship. Conducting empirical studies in various business sectors and organizations, and in many countries would examine and enhance the validity of the proposed framework, thereby contributing to the possibility of generalizing results and making the framework variables them more reliable. Table 1 reviews the development of the proposed framework.

Table 1. Proposed framework development.

\begin{tabular}{l|l|l|l|l|l}
\hline $\begin{array}{l}\text { Shannon and } \\
\text { Weaver (1949) }\end{array}$ & \multicolumn{2}{|c|}{$\begin{array}{c}\text { Technical } \\
\text { Level }\end{array}$} & \multicolumn{1}{c|}{$\begin{array}{c}\text { Semantic } \\
\text { Level }\end{array}$} & \multicolumn{2}{c}{ Effectiveness/Impact } \\
\hline Mason (1978) & Production & Product & Receipt & $\begin{array}{l}\text { Effect on } \\
\text { Recipient }\end{array}$ & $\begin{array}{l}\text { Effect } \\
\text { System }\end{array}$ \\
\hline $\begin{array}{l}\text { DeLone and } \\
\text { McLean (1992) }\end{array}$ & Quality of System & $\begin{array}{l}\text { Quality of } \\
\text { Information }\end{array}$ & $\begin{array}{l}\text { Usage \& User } \\
\text { Satisfaction }\end{array}$ & $\begin{array}{l}\text { Individual } \\
\text { Impact }\end{array}$ & $\begin{array}{l}\text { Organizational } \\
\text { Impact }\end{array}$ \\
\hline $\begin{array}{l}\text { DeLone and } \\
\text { McLean (2003) }\end{array}$ & $\begin{array}{l}\text { Quality } \\
\text { of } \\
\text { System }\end{array}$ & $\begin{array}{l}\text { Quality } \\
\text { of } \\
\text { Service }\end{array}$ & $\begin{array}{l}\text { Quality of } \\
\text { Information }\end{array}$ & $\begin{array}{l}\text { Usage / Intention } \\
\text { to Usage \& } \\
\text { Satisfaction of User }\end{array}$ & Net Benefits \\
\hline $\begin{array}{l}\text { DeLone and } \\
\text { McLean (2003) } \\
\text { modified }\end{array}$ & $\begin{array}{l}\text { Quality } \\
\text { of } \\
\text { System }\end{array}$ & $\begin{array}{l}\text { Quality } \\
\text { of } \\
\text { Service }\end{array}$ & $\begin{array}{l}\text { Quality of } \\
\text { Information }\end{array}$ & $\begin{array}{l}\text { Usage / Intention } \\
\text { to Usage \& } \\
\text { Satisfaction of User }\end{array}$ & Net Impacts \\
\hline $\begin{array}{l}\text { ISs-CM Model) } \\
\text { Proposed }\end{array}$ & $\begin{array}{l}\text { Quality } \\
\text { of } \\
\text { Framework }\end{array}$ & $\begin{array}{l}\text { Quality } \\
\text { of } \\
\text { Service }\end{array}$ & $\begin{array}{l}\text { Quality of } \\
\text { Information }\end{array}$ & $\begin{array}{l}\text { Use \& User } \\
\text { Satisfaction }\end{array}$ & $\begin{array}{l}\text { Net Impacts (Crisis } \\
\text { Management) }\end{array}$ \\
\hline
\end{tabular}

\section{PROPOSED MEASURES}

To evaluate the success of information systems, the DeLone and McLean (2003) model was adopted, which contains two categories: information systems quality, and effectiveness. Each category consists of a number of dimensions. Information systems quality includes three dimensions: quality of system, information, and service. The effectiveness category includes two dimensions: Usage/usability, and user satisfaction. Each dimension incorporates a number of factors, as follows: Systems quality relates to ease of learning, understanding and use, flexibility, integration, response time, reliability, and availability. Information quality relates to relevance, accuracy, completeness, timeliness, understandability, format, comparability, verifiability, predictability. The quality of services relates to responsiveness, empathy, reliability, assurance, tangibles. Usage/Usability relates to frequency, reports requested, duration, and expectation. User satisfaction relates to overall satisfaction, performance, needs, participation, and training.

To measure its effectiveness, crisis management was divided into three chronological categories or stages, namely: pre-crisis management, management during the crisis, and post-crisis management. Each stage has specific assigned tasks to perform. The pre-crisis stage has two primary tasks: signal detection, and preparation and prevention. The during-crisis stage has one primary task: containment and damage limitation. The post-crisis stage has two primary tasks: recovery and learning. Furthermore, each task has particular requirements focused around it for its successful completion. These requirements include organizational support, organizational culture, control and monitoring, training, instructions and regulations, planning, participation, coordination, communication and cooperation, information systems, information, databases, analysis, tasks and powers, awareness, motivation and reward, decision-making, resource allocation and rationalization, time recognition, work teams, experiences, evaluation, and learning.

\section{PROPOSED EMPIRICAL PATHS}

In order to have an accurate understanding of the proposed framework, it is necessary to clarify the experimental paths that can be tested in practice so that the measurement process can be facilitated and the relationships between variables can be determined. Based on the proposed framework, it is clear that the core objective is to measure the impact of the success of information systems on the effectiveness of crisis management, and this shows the direction 
of the main experimental path. There are experimental paths between the dimensions of information systems and both system usage and satisfaction of user, as there is also a path between system use and user satisfaction, and vice versa due to the mutual relationship between them. There is a path between both usage and user satisfaction on crisis management effectiveness since it represents the level of nett final impact of this framework. It is also possible to form more detailed paths of the relationship between the variables, and these paths are represented in the associations between the dimensions of the success of the information system and the categories of crisis management effectiveness. Table 2, Table 3, Table 4, and Table 5 illustrate these potential relationships.

Table 2. Paths among different dimensions of information systems success.

\begin{tabular}{|c|c|c|c|}
\hline$\#$ & Independent Variables & Paths & Dependent Variables \\
\hline \multicolumn{4}{|c|}{ Path systems dimensions and system use. } \\
\hline 1. & Quality of System & $\longrightarrow$ & System Usage \\
\hline 2. & Quality of Information & $\longrightarrow$ & System Usage \\
\hline 3. & Quality of Service & $\longrightarrow$ & System Usage \\
\hline \multicolumn{4}{|c|}{ Path systems dimensions and user satisfaction. } \\
\hline 4. & Quality of System & $\longrightarrow$ & Satisfaction of User \\
\hline 5. & Quality of Information & $\longrightarrow$ & Satisfaction of User \\
\hline 6. & Quality of Service & $\rightarrow$ & Satisfaction of User \\
\hline \multicolumn{4}{|c|}{ Reversal path, system use and user satisfaction. } \\
\hline 7. & System Usage & $\longrightarrow$ & Satisfaction of User \\
\hline 8. & Satisfaction of User & $\longrightarrow$ & System Usage \\
\hline
\end{tabular}

Table 3. Paths between the dimensions of information system success and crisis management effectiveness.

\begin{tabular}{l|l|l|l}
\hline$\#$ & Independent Variables & Paths & Dependent Variables \\
\hline Path of information systems success dimensions and crisis management effectiveness. \\
\hline 1. & System Quality & $\longrightarrow$ & Crisis Management Effectiveness \\
\hline 2. & Information Quality & $\longrightarrow$ & Crisis Management Effectiveness \\
\hline 3 & Service Quality & $\longrightarrow$ & Crisis Management Effectiveness \\
\hline 4. & System Use & $\longrightarrow$ & Crisis Management Effectiveness \\
\hline 5. & User Satisfaction & $\longrightarrow$ & Crisis Management Effectiveness \\
\hline Path of information systems success dimensions and pre-crisis management category. \\
\hline 6. & System Quality & $\longrightarrow$ & Pre-crisis Management \\
\hline 7. & Information Quality & $\longrightarrow$ & Pre-crisis Management \\
\hline 8. & Service Quality & $\longrightarrow$ & Pre-crisis Management \\
\hline 9. & System Use & $\longrightarrow$ & Pre-crisis Management \\
\hline 10. & User Satisfaction & $\longrightarrow$ & Pre-crisis Management \\
\hline Path of information systems success dimensions and during-crisis management category. \\
\hline 11. & System Quality & $\longrightarrow$ & During-crisis Management \\
\hline 12. & Information Quality & $\longrightarrow$ & During-crisis Management \\
\hline 13. & Service Quality & $\longrightarrow$ & During-crisis Management \\
\hline 14. & System Use & $\longrightarrow$ & During-crisis Management \\
\hline 15. & User Satisfaction & $\longrightarrow$ & During-crisis Management \\
\hline Path of information systems success dimensions and post-crisis management category. \\
\hline 16. & System Quality & $\longrightarrow$ & Post-crisis Management \\
\hline 17. & Information Quality & $\longrightarrow$ & Post-crisis Management \\
\hline 18. & Service Quality & $\longrightarrow$ & Post-crisis Management \\
\hline 19. & System Use & Post-crisis Management \\
\hline 20. & User Satisfaction & Post-crisis Management \\
\hline
\end{tabular}


Table 4. System use mediating paths between information systems success dimensions and crisis management effectiveness.

\begin{tabular}{l|l|l|l|l|l}
\hline$\#$ & Independent Variables & Paths & Mediator variable & Paths & Dependent Variables \\
\hline \multicolumn{2}{|l|}{ System use mediates the path of systems dimensions and crisis management effectiveness. } \\
\hline 1. & System Quality & $\longrightarrow$ & System Use & $\longrightarrow$ & Crisis Management Effectiveness \\
\hline 2. & Information Quality & $\longrightarrow$ & System Use & $\longrightarrow$ & Crisis Management Effectiveness \\
\hline 3. & Service Quality & $\longrightarrow$ & System Use & $\longrightarrow$ & Crisis Management Effectiveness \\
\hline
\end{tabular}

System use mediates the path of systems dimensions and pre-crisis management category.

\begin{tabular}{l|l|l|l|l|l}
\hline 4. & System Quality & & System Use & $\longrightarrow$ & Pre-crisis management \\
\hline 5. & Information Quality & $\longrightarrow$ & System Use & $\longrightarrow$ & Pre-crisis management \\
\hline 6. & Service Quality & $\longrightarrow$ & System Use & $\longrightarrow$ & Pre-crisis management
\end{tabular}

System use mediates the path of systems dimensions and during-crisis management category.

\begin{tabular}{l|l|l|l|l|l}
\hline 7. & System Quality & $\longrightarrow$ & System Use & $\longrightarrow$ & During-crisis management \\
\hline 8. & Information Quality & $\longrightarrow$ & System Use & $\longrightarrow$ & During-crisis management \\
\hline 9. & Service Quality & $\longrightarrow$ & System Use & $\longrightarrow$ & During-crisis management \\
\hline
\end{tabular}

System use mediates the path of systems dimensions and post-crisis management category.

\begin{tabular}{l|l|l|l|l|l}
\hline 10. & System Quality & $\longrightarrow$ & System Use & $\longrightarrow$ & Post-crisis management \\
\hline 11. & Information Quality & $\longrightarrow$ & System Use & $\longrightarrow$ & Post-crisis management \\
\hline 12. & Service Quality & $\longrightarrow$ & System Use & $\longrightarrow$ & Post-crisis management \\
\hline
\end{tabular}

Table 5. User satisfaction mediating paths between the dimensions of information system success and crisis management effectiveness

\begin{tabular}{l|l|l|l|l|l}
\hline$\#$ & Independent Variables & Paths & Mediator Variable & Paths & Dependent Variables \\
\hline User satisfaction mediates the path of systems dimensions and crisis management effectiveness. \\
\hline 1. & System Quality & $\longrightarrow$ & User Satisfaction & $\longrightarrow$ & Crisis Management Effectiveness \\
\hline 2. & Information Quality & $\longrightarrow$ & User Satisfaction & $\longrightarrow$ & Crisis Management Effectiveness \\
\hline 3. & Service Quality & $\longrightarrow$ & User Satisfaction & $\longrightarrow$ & Crisis Management Effectiveness \\
\hline User satisfaction mediates the path of systems dimensions and pre-crisis management category. \\
\hline 4. & System Quality & $\longrightarrow$ & User Satisfaction & $\longrightarrow$ & Pre-crisis management \\
\hline 5. & Information Quality & $\longrightarrow$ & User Satisfaction & $\longrightarrow$ & Pre-crisis management \\
\hline 6. & Service Quality & $\longrightarrow$ & User Satisfaction & $\longrightarrow$ & Pre-crisis management \\
\hline User satisfaction mediates the path of systems dimensions and during-crisis management category. \\
\hline 7. & System Quality & $\longrightarrow$ & User Satisfaction & $\longrightarrow$ & During-crisis management \\
\hline 8. & Information Quality & $\longrightarrow$ & User Satisfaction & $\longrightarrow$ & During-crisis management \\
\hline 9. & Service Quality & $\longrightarrow$ & User Satisfaction & $\longrightarrow$ & During-crisis management \\
\hline User satisfaction mediates the path of systems dimensions and post-crisis management category. \\
\hline 10. & System Quality & $\longrightarrow$ & User Satisfaction & $\longrightarrow$ & Post-crisis management \\
\hline 11. & Information Quality & $\longrightarrow$ & User Satisfaction & $\longrightarrow$ & Post-crisis management \\
\hline 12. & Service Quality & $\longrightarrow$ & User Satisfaction & $\longrightarrow$ & Post-crisis management \\
\hline
\end{tabular}

\section{CONCLUSION}

In our review of the literature on the success of information systems and crisis management, we found few studies linking the two dimensions. We also noted the scarcity of practical models that measure the effectiveness of crisis management. Moreover, there is no integrated empirical model that regulates the association between the success of information system and crisis management, despite the diversity of these information systems and the multiplicity of types of crises, and this constitutes an important research gap that requires further research. Therefore, this paper set out to create a comprehensive and integrated framework that facilitates the process of measuring the association between information system success and the effectiveness of crisis management, and to make it accessible to all empirical studies in this field so that it can be applied to various information systems and different types of crises. In addition to the framework, the paper has presented comprehensive measures of the information system success in the light of the DeLone and McLean (2003) model, and a literature review, as well as comprehensive measures related to crisis management derived from Mitroff's model, suitable for all kinds of crises, which subsequent empirical studies can use, taking into account the specificity and nature of each crisis. It has also presented a proposal for possible 
experimental paths between the variables of that framework that could be explored to facilitate understanding and more accurate measurement. This paper emphasizes the need to pay attention to the impact aspect of information systems. It is necessary to conduct more experimental research to measure the validity of the proposed framework to better understand the nature of the relationship between variables and the generalizability of the subsequent results.

Funding: The research article is fully funded by University Technology MARA, Malaysia.

Competing Interests: The authors declare that they have no competing interests.

Authors' Contributions: All authors contributed equally to the conception and design of the study.

\section{REFERENCES}

A'dwan, M. S. (2019). The effectiveness of management information systems and its role in improving crisis management: Empirical study in ministries of social development and labor in Gaza Strip. Master Thesis. Gaza, Palestine: Al-Azhar University-Gaza.

Abdalbaqi, A. M. (2021). A qualitative study for crisis management strategies used by small business leaders. Doctoral Thesis. Chicago, United States: Concordia University Chicago.

Abdul Razzaq, M. S. (2011). Crisis management and information systems to the extent of impact and effectiveness An applied study in a number of tourism companies listed in the Iraqi capital market. Journal of Baghdad College of Economic Sciences University(28), 144-165.

Abualoush, S. H., Obeidat, A. M., Tarhini, A., \& Al-Badi, A. (2018). The role of employees' empowerment as an intermediary variable between knowledge management and information systems on employees' performance. VINE Journal of Information and Knowledge Management Systems, 48(2), 217-237.Available at: https://doi.org/10.1108/vjikms-08-20170050.

AL-Ja'afreh, A. B. (2011). Quality management for information systems effectiveness: An empirical study of Jordanian industrial firms. PhD Thesis. Amman, Jordan: University of Banking and Financial Sciences.

Al Eid, N. A., \& Arnout, B. A. (2020). Crisis and disaster management in the light of the Islamic approach: COVID-19 pandemic crisis as a model (a qualitative study using the grounded theory). Journal of Public Affairs, 20(4), 1-14.Available at: https://doi.org/10.1002/pa.2217.

Aldao, C., Blasco, D., Espallargas, M. P., \& Rubio, S. P. (2021). Modelling the crisis management and impacts of 21 st century disruptive events in tourism: The case of the COVID-19 pandemic. Tourism Review, 76(4), 929-941.Available at: https://doi.org/10.1108/TR-07-2020-0297.

Aldegis, A. M. (2018). Impact of accounting information systems' quality on the relationship between organizational culture and accounting information in Jordanian industrial public shareholding companies. International Journal of Academic Research in Accounting, Finance and Management Sciences, 8(1), 7-80.Available at: http://dx.doi.org/10.6007/IJARAFMS/v8i1/3829.

Aldholay, A. H., Isaac, O., Abdullah, Z., \& Ramayah, T. (2018). The role of transformational leadership as a mediating variable in DeLone and McLean information system success model: The context of online learning usage in Yemen. Telematics and Informatics, 35(5), 1421-1437.Available at: https://doi.org/10.1016/j.tele.2018.03.012.

Ali, B. M., \& Younes, B. (2013). The impact of information systems on user performance: An exploratory study. Journal of Knowledge Management, Economics and Information Technology, 3(2), 1-10.

Aloun, M. L., \& Attieh, H. (2018). The effectiveness of management information system and its contribution to crises management "case study of (Caterpillar) and (Johnson \& Johnson) companies. Al-Afak Journal for Economic Studies, 3(1), 99-115.

Alpaslan, C. M., \& Mitroff, I. I. (202 1). Exploring the moral foundations of crisis management. Technological Forecasting and Social Change, 167, 1-9.Available at: https://doi.org/10.1016/j.techfore.2021.120713.

Alteneiji, H. R., Ahmed, V., \& Saboor, S. (2020). A qualitative approach to investigate emergency preparedness state for the built environment in the UAE. Engineering, Construction and Architectural Management, 28(7), 2005-2022.Available at: https://doi.org/10.1108/ECAM-05-2020-0296. 
Bakir, H. M. (2016). Obstacles in the achievement of the major municipalities of the Gaza Strip for their services during emergency situations. Master Thesis. Gaza, Palestine: The Islamic University of Gaza.

Barbakh, N. I. (2013). Evaluation of electronic accounting information systems in Palestinian universities in Gaza Strip-Field study. Master Thesis. Gaza, Palestine: The Islamic University of Gaza.

Berbekova, A., Uysal, M., \& Assaf, A. G. (2021). A thematic analysis of crisis management in tourism: A theoretical perspective. Tourism Management, 86, 1-13.Available at: https://doi.org/10.1016/j.tourman.2021.104342.

Cahyono, D., \& Suryani, E. (2020). The suitability evaluation of procurement information systems to the needs of users and management using human, organization, technology-fit (HOT-Fit) framework. IPTEK The Journal for Technology and Science, 31(1), 101-110.Available at: https://doi.org/10.12962/j20882033.v31i1.6326.

Chabani, M., \& Chabani, W. (2014). Managing financial crises according to accounting information systems. Journal of Economics and Applied Statistics, 11(1), 196-206.

Chahed, A. H., \& Zergoune, M. (2017). Effectiveness of information systems in crisis management. The Journal of Economic and Financial Studies, $10(3), 145-151$.

Dayour, F., Adongo , C. A., Amuquandoh, F. E., \& Adam, I. (2020). Managing the COVID-19 crisis: Coping and post-recovery strategies for hospitality and tourism businesses in Ghana. Journal of Hospitality and Tourism Insights, 4(4), 373392.Available at: https://doi.org/10.1 108/JHTI-08-2020-0150.

DeLone, W. H., \& McLean, E. R. (1992). Information systems success: The quest for the dependent variable. Information Systems Research, 3(1), 60-95.Available at: https://doi.org/10.1287/isre.3.1.60.

DeLone, W. H., \& McLean, E. R. (2002). Information systems success revisited. Paper presented at the Proceedings of the 35th Hawaii International Conference on System Sciences, Big Island, Hawaii.

DeLone, W. H., \& McLean, E. R. (2003). The DeLone and McLean model of information systems success: A ten-year update. Journal of Management Information Systems, 19(4), 9-30.Available at: https://doi.org/10.1080/0742 1222.2003.1 1045748.

DeLone, W. H., \& McLean, E. R. (2016). Information systems success measurement. Foundations and Trends in Information Systems, 2(1), 1-116.Available at: https://doi.org/10.1561/2900000005.

Dwivedi, Y. K., Hughes, L., Ismagilova, E., Aarts, G., Coombs, C., Crick, T., \& Eirug, A. (2021). Artificial Intelligence (AI): Multidisciplinary perspectives on emerging challenges, opportunities, and agenda for research, practice and policy. International Journal of Information Management, 57, 101994.

Ekman, P., Dahlin, P., \& Keller, C. (2021). Management and information technology after digital transformation. New York: Routledge. Ershadi, M. M., \& Shemirani, H. S. (2021). A multi-objective optimization model for logistic planning in the crisis response phase. Journal of Humanitarian Logistics and Supply Chain Management, 12(1), 30-53.Available at: https://doi.org/10.1108/JHLSCM-11-2020-0108.

Ferwanah, H. A. (2019). The importance of crisis management in improving the quality of health services for patients in hospitals in the Gaza Strip. Journal of Business and Finance Economy, 3(2), 233-265.

Ghanem, M. M. (2011). The role of information technology in crisis management for employees in the operations rooms of the security services of the Palestinian Ministry of Interior. Master Thesis. Hebron, Palestine: Hebron University.

Ghoneim, M. A. (2004). The role of computerized management information systems in the decision-making process in the municipalities of the Gaza Strip in Palestine. Master Thesis. Gaza, Palestine: The Islamic University of Gaza.

Gorla , N., Somers, T. M., \& Wong, B. (2010). Organizational impact of system quality, information quality, and service quality. Journal of Strategic Information Systems, 19, 207-228.Available at: https://doi.org/10.1016/j.jsis.2010.05.001.

Gudipudi, S. N., \& Srivastav, A. K. (2016). Analyzing the uses of management and accounting information system in business organizations. International Journal in Management and Social Science, 4(2), 783-790.

Hanna, R. D., Abdul Aziz, S. K., \& Najib, S. H. (2018). The role of management information system in crisis management an empirical study in some faculties of the university of Mosul. Journal of Kirkuk University for Administrative and Economic Sciences, 8(2), 115-140. 
Jaafreh, A. B. (2017). Evaluation information system success: Applied DeLone and McLean information system success model in context banking system in KSA. International Review of Management and Business Research, 6(2), 829-845.

Kanakriyah, R. (2016). The effect of using accounting information systems on the quality of accounting information according to users perspective in Jordan. European Journal of Accounting, Auditing and Finance Research, 4(11), 58-75.

Kao, G. H.-Y., Wang, S. W., \& Farquhar, J. D. (2020). Modeling airline crisis management capability: Brand attitude, brand credibility and intention. Journal of Air Transport Management, 89, 101894.Available at: https://doi.org/10.1016/j.jairtraman.2020.101894.

Le, D., \& Phi, G. (2021). Strategic responses of the hotel sector to COVID-19: Toward a refined pandemic crisis management framework. International Journal of Hospitality Management, 94, 1-5.Available at: https://doi.org/10.1016/j.ijhm.2020.102808.

Leta, S. D., \& Chan, I. C. (2021). Learn from the past and prepare for the future: A critical assessment of crisis management research in hospitality. International Journal of Hospitality Management, 95, 1-11.Available at: https://doi.org/10.1016/j.ijhm.2021.102915.

Mason, R. O. (1978). Measuring information output: A communication systems approach. Information $\Xi^{2}$ Management, 1(4), $219-$ 234.Available at: https://doi.org/10.1016/0378-7206(78)90028-9.

Mitroff, I. I., Shrivastava, P., \& Udwadia, F. E. (1987). Effective crisis management. Academy of Management Perspectives, 1(4), 283292.

Mitroff, I. I. (1994). The role of computers and decision aids in crisis management: A developer's report. Journal of Contingencies and Crisis Management, 2(2), 73-84.Available at: https://doi.org/10.1111/j.1468-5973.1994.tbooo28.x.

Mkonya, V. L., Jintian, Y., \& Kyando, N. (2017). Effect of using accounting information system on accounting information quality for projects. Paper presented at the Proceedings of the 14th International Conference on Innovation \& Management. Wuhan, China: Wuhan University of Technology Press.

Nizamidou, C., \& Vouzas, F. (2020). The contribution of preoccupation with failure to TQM, crisis management and HR aiming to overcome crises. The TQM Journal, 32(6), 1077-1098.Available at: https://doi.org/10.1 108/TQM-11-2019-0265.

Nurhayati, N., Iss, A., \& Sk, R. (2017). The influence of personal information capability and management commitment on the success of the implementation of accounting information system in Baznas of District-City level in West Java Province. International Journal of Advanced Engineering, Management and Science, 3(7), 803-810.Available at: https://doi.org/10.24001/ijaems.3.7.13.

Pearson, C. M., \& Mitroff, I. I. (1993). From crisis prone to crisis prepared: A framework for crisis management. Academy of Management Perspectives, 7(1), 48-59.Available at: https://doi.org/10.5465/ame.1993.9409142058.

Pohan, M. (2021). Analysis of the role of management information systems in the decision making process at PT. Indonesian trading company Medan. Paper presented at the Journal of International Conference Proceedings (JICP).

Putra, W. E., \& Setiawan, D. (2020). The success analysis of implementation of the electronic system integrated final project of Jambi University students with Delone and Mclean model approach. Journal of Islamic Economics and Business, 4(2), 147154.Available at: http://dx.doi.org/10.15548/jebi.v4i2.241.

Rahi, S., \& AbdGhani, M. (2019). Integration of DeLone and McLean and self-determination theory in internet banking continuance intention context. International Journal of Accounting \& Information Management, 27(3), 512-528.Available at: https://doi.org/10.1108/IJAIM-07-2018-0077.

Ravichandran, T. (2018). Exploring the relationships between IT competence, innovation capacity and organizational agility. The Journal of Strategic Information Systems, 27(1), 22-42.Available at: https://doi.org/10.1016/j.jsis.2017.07.002.

Ricke, M. L. (2020). Did you take care of everybody? Insights on crisis management from senior student affairs professionals. PhD Thesis. Greeley, Colorado, United States: University of Northern Colorado.

Romi, I. M. (2013). Testing Delone and Mclean's model in financial institutions. American Academic \& Scholarly Research Journal, 5(3), 121-129. 
Sedera, D., \& Gable, G. (2004). A factor and structural equation analysis of the enterprise systems success measurement model. Paper presented at the Twenty-Fifth International Conference on Information Systems.

Shagari, S. L. (2018). Determinants of accounting information technology usage in Nigerian banking sector. PhD Thesis. Kedah, Malaylia: Universiti Utara Malaylia.

Shamim, S., Zeng, J., Shariq, S. M., \& Khan, Z. (2019). Role of big data management in enhancing big data decision-making capability and quality among Chinese firms: A dynamic capabilities view. Information \& Management, 56(6), 103135.Available at: https://doi.org/10.1016/j.im.2018.12.003.

Shannon, C. E., \& Weaver, W. (1949). The mathematical theory of communication. Urbana: The University of Illinois Press.

Sofyan, A. S., Abror, A., Putra, T. W., Muslihati, M., Sofyan, S., Sirajuddin, S., \& Darussalam, A. Z. (202 1). Crisis and disaster management for halal tourism: A systematic review. Tourism Review, 1-7.Available at: https://doi.org/10.1108/TR-082020-0390.

Sorongan, E., \& Hidayati, Q. (2020). Integration of eucs variables into Delone and Mclean models for egovernment evaluation: Conceptual models. Scientific Journal of Information System Technology, 6(1), 33-43.Available at: https://doi.org/10.26594/register.v6i1.1608.

Spanò, R., \& Ferri, L. (2019). Information systems in healthcare. Newcastle Upon Tyne, UK: Cambridge Scholars Publishing.

Sumukadas, N. (2021). Are you ready for your next product recall crisis? Lessons from operations and supply chain management. Business Horizons, 64(2), 21 1-221.Available at: https://doi.org/10.1016/j.bushor.2020.12.001.

Susanto, A. (2017). How the quality of accounting information system impact on accounting information quality (Research on Higher Education in Bandung). Journal of Engineering and Applied Sciences, 12(14), 3672-3677.Available at: https://doi.org/10.36478/jeasci.2017.3672.3677.

Susilawati, C. D., \& Jerry. (2018). Influence of implementation of quality of accounting information systems to generate quality of accounting information in higher education. National Academy of Managerial Staff of Culture and Arts Herald, 1, 791-795.

Tam, C., \& Oliveira, T. (2016). Understanding the impact of m-banking on individual performance: DeLone \& McLean and TTF perspective. Computers in Human Behavior, 61, 233-244.Available at: https://doi.org/10.1016/j.chb.2016.03.016.

Thielsch, M. T., Roseler, S., Kirsch, J., Lamers, C., \& Hertel, G. (2020). Managing pandemics demands, resources, and effective behaviors within crisis management teams. Applied Psychology: An International Review, 7O(1), 150-187.Available at: https://doi.org/10.1111/apps.12303.

Tokakis, V., Polychroniou, P., \& Boustras, G. (2019). Crisis management in public administration: The three phases model for safety incidents. Safety Science, 113, 37-43.Available at: https://doi.org/10.1016/j.ssci.2018.11.013.

West, H. M. (2020). Assessing school crisis plans: Development of the school crisis assessment and logistical evaluation. PhD Thesis. Stillwater, Oklahoma, US: Oklahoma State University.

Wu , J.-H., \& Wang, Y.-M. (2006). Measuring KMS success: A respecification of the DeLone and McLean’s model. Information \& Management, 43, 728-739.Available at: https://doi.org/10.1016/j.im.2006.05.002.

Wut, T. M., Xu, J., \& Wong, S.-M. (2021). Crisis management research (1985-2020) in the hospitality and tourism industry: A review and research agenda. Tourism Management, $85, \quad$ 1-28.Available at https://doi.org/10.1016/j.tourman.2021.104307.

Zwyalif, I. M. (2015). Success of accounting information systems and their impact on the stages of crises management. Dirasat, Administrative Sciences, 42(1), 247-266.

Views and opinions expressed in this article are the views and opinions of the author(s), International Journal of Asian Social Science shall not be responsible or answerable for any loss, damage or liability etc. caused in relation to/arising out of the use of the content. 